\title{
Retraction: Identification of volatile constituents released from IQOS heat-not- burn tobacco HeatSticks using a direct sampling method
}

Ilies BD, Moosakutty SP, Kharbatia NM, et al. Identification of volatile constituents released from IQOS heat-not-burn tobacco HeatSticks using a direct sampling method. Tob Control Published Online First: 26 May 2020. doi: 10.1136/tobaccocontrol-2019-055521

This article has been retracted at the request of the authors after inaccuracies in the referencing and methodological issues were discovered.

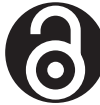

\section{OPEN ACCESS}

Open access This is an open access article distributed in accordance with the Creative Commons Attribution Non Commercial (CC BY-NC 4.0) license, which permits others to distribute, remix, adapt, build upon this work noncommercially, and license their derivative works on different terms, provided the original work is properly cited, appropriate credit is given, any changes made indicated, and the use is non-commercial. See: http://creativecommons.org/licenses/by-ncl 4.0\%.

(c) Author(s) (or their employer(s)) 2021. Re-use permitted under CC BY-NC. No commercial re-use. See rights and permissions. Published by BMJ.

Tob Control 2021;30:478. doi:10.1136/tobaccocontrol-2019-055521ret

D) Check for updates 